\title{
In Vitro Cytotoxicity of Latex Orthodontic Elastics
}

\author{
Citotoxicidad de los Elásticos Ortodónticos de Látex
}

\author{
Rogério Lacerda dos Santos*; Matheus Melo Pithon*; \\ Fernanda Otaviano Martins ${ }^{* *}$ \& Maria Teresa Villela Romanos ${ }^{* * *}$
}

DOS SANTOS, L. R.; PITHON, M. M.; MARTIS, O. F. \& ROMANOS, V. M. T. In vitro cytotoxicity of latex orthodontic elastics. Int. J. Odontostomat., 4(1):81-85, 2010.

\begin{abstract}
Natural latex does not fall into the category of materials known to be entirely inoffensive. The objective of the present in vitro study is to test the hypothesis that there is no difference in the cytotoxicity between natural latex elastics of different colours. The present article compared different latex intra-oral elastics $(5 / 16=7.9 \mathrm{~mm})$. The sample was divided into four groups according to their manufacturer: Group N (Natural latex elastic, Morelli), Group R (Red colour elastic, Morelli) Group Y (Yellow colour elastic, Morelli) and Group G (Green colour elastic, Morelli). Cytotoxicity assays were performed by using cell culture medium containing L-929 line cells (mouse fibroblast). The cytotoxicity was evaluated by using the "dyeuptake" test, which was employed at two different moments (1 and $24 \mathrm{~h}$ ). Data were compared by analysis of variance (ANOVA) and Tukey's test $(p<0.05)$. The results showed a significant difference $(p<0.05)$ between the groups $N, R, Y, G$ and the negative cytotoxicity control at 1 and $24 \mathrm{~h}(\mathrm{p}<0.05)$, it did not have presented significant difference between the groups $\mathrm{N}$, $\mathrm{R}, \mathrm{Y}, \mathrm{G}$ tested $(\mathrm{p}>0.05)$ at 1 and $24 \mathrm{~h}$. Morelli intra-oral elastics were found to be highly cytotoxic, regardless of their colour and immersion time.
\end{abstract}

KEY WORDS: cytotoxicity, elastics, biocompatibility, orthodontics.

\section{INTRODUCTION}

Recent studies have been concerned with the biocompatibility of different types of orthodontic materials (Kao et al., 2007; Vande Vannet \& Hanssens, 2007), such as latex (Santos et al., 2008). Because natural latex rubber has been increasingly used as dental material, many cytotoxicity issues have been reported as well (Hwang \& Cha, 2003). Conservants such as sulphur and zinc oxide as well as antioxidants such as di-thio-carbohydrates, N-nitrosodibutylamine, and $\mathrm{N}$-nitrosopiperidine are all known to be cytotoxic substances (Fiddler et al., 1992).

Although case reports on latex allergy is not so frequently seen in the literature, allergic reactions have been relatively prevalent as latex-based products become commercially available. Most of the allergic reactions (Snyder \& Settle, 1994) have been related to the use of orthodontic elastics (Neiburger, 1991), which is characterised by presence of small vesicles or acute edema and complaints of itching and burning.
Prevulcanised latex is produced by mixing pure natural latex, which has the highest molecular weight (Weiss \& Hirshman, 1992), with stabilisers such as zinc oxide and chemically vulcanised materials. The resulting mixture is then heated until $70^{\circ} \mathrm{C}$ (Perrella \& Gaspari, 2002). Although zinc is known to be neurotoxic (Lobner \& Asrari, 2003), the amount released by orthodontic elastics can be ingested as research studies show no evidence of harm (Hanson \& Lobner, 2004). Anti-ozone and antioxidant agents are also added to latex during the manufacture of orthodontic elastics (Weiss \& Hirshman). This process has the advantage of producing latex with higher mechanical properties, thus increasing its strength and elasticity (Perrella \& Gaspari; Hanson \& Lobner).

As these materials are widely used in clinical orthodontics, care regarding the cytotoxicity of orthodontic elastics should be taken, mainly with regard to intra-oral elastics as they have a very close contact with gingival and mucosa.

\footnotetext{
Specialist in Orthodontics at the Federal University of Alfenas, Minas Gerais, Brazil. Master in Orthodontics at the Federal University of Rio de Janeiro, Brazil. PhD student in orthodontics at the Federal University of Rio de Janeiro, Brazil.

" Graduated in Biological Sciences: Microbiology and Immunology Federal University of Rio de Janeiro-UFRJ, Brazil.

${ }^{* * *}$ Microbiology Assistant Professor at the Federal University of Rio de Janeiro-UFRJ, Brazil.
} 
The use of cell culture medium for testing the toxicity of dental products is a valid way of understanding the biological behaviour of such materials (Schmalz, 1994). The objective of the present in vitro study is to test the hypothesis that there is no difference in the cytotoxicity between natural latex elastics of different colours.

\section{MATERIAL AND METHOD}

Latex intra-oral elastics of different colours (5/16" $=7.9 \mathrm{~mm}$ ), were selected for studying their cytotoxicity in cell culture (Table I). The samples were divided into four groups according to their manufacturer: Group N (Natural latex elastic, Morelli, Sorocaba, São Paulo, Brazil), Group R (Red colour elastic, Morelli, Sorocaba, São Paulo, Brazil) Group Y (Yellow colour elastic, Morelli, Sorocaba, São Paulo, Brazil) and Group G (Green colour elastic, Morelli, Sorocaba, São Paulo, Brazil) (Fig. 1).

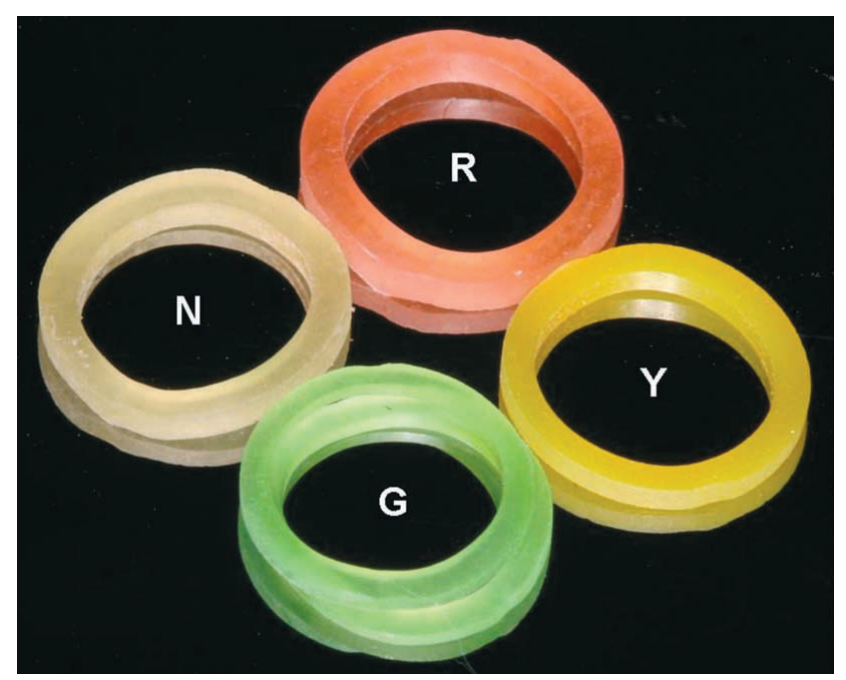

Fig. 1. Latex intra-oral elastics evaluated in this study: $\mathrm{N}(\mathrm{Na}-$ tural latex elastic), R (Red colour elastic), Y (Yellow colour elastic) and $\mathrm{G}$ (Green colour elastic).

All samples had recent manufacturing dates, from the same production lot and came in sealed plastic packages. The elastics of experimental and control groups had their both sides previously sterilised with ultraviolet light (Labconco, Kansas, Missouri) during 30 minutes (Santos et al.). Then $4 \mathrm{~g}$ of each material was taken, washed with Deionized water (Millipore, Bedford, MA, USA) and dried. Dental copper amalgam (Vigodent, Rio de Janeiro, Brazil) with standard size and weight was used as positive control, whereas stainless steel wire (American Orthodontics, Sheboygan, Wisconsin) was used as negative control (Table I).
Cell culture containing L-929 line cells (mouse fibroblast) (American Type Culture Collection - ATCC, Rockville, MD) was maintained in Eagles' minimum essential medium (Cultilab, Campinas, Brazil) by adding $0.03 \mathrm{mg} / \mathrm{ml}$ of glutamine (Sigma, St. Louis, Missouri), 50 $\mu \mathrm{g} / \mathrm{ml}$ of garamicine (Schering Plough, Kenilworth, New Jersey), $2.5 \mathrm{mg} / \mathrm{ml}$ of fungizone (Bristol-Myers-Squibb, New York, USA.), $0.25 \%$ sodium bicarbonate solution (Merck, Darmstadt, Germany), 10 mM of HEPES (Sigma, St. Louis, Missouri), and 10\% bovine fetal serum (Cultilab, Campinas, Brazil) for growth medium or no bovine fetal serum for maintenance medium only. Next, the cell culture medium was incubated at $37 \mathrm{oC}$ for 48 hours.

The method for evaluating the cytotoxicity was the "dye-uptake" test (Neyndorff et al., 1990). This method is based on neutral red dye incorporated into live cells. It was used in this experiment only at two periods of evaluation: 1 and $24 \mathrm{~h}$. The 1-hour period represents the maintenance of the elastic in the cell culture medium for $1 \mathrm{~h}$ after removal, whereas the 24hour period represents the maintenance of the elastic in the cell culture medium for $24 \mathrm{~h}$ after removal.

Dye-uptake. Volumes of $100 \mu \mathrm{l}$ of L-929 line cells were distributed into 96 -well microplates. After 48 hours, the growth medium was replaced with $100 \mu$ l of Eagles' minimum essential medium (MEM) obtained following incubation in the different types of elastics at 1 and 24 hours. Positive and negative control groups consisted of culture medium put in contact with amalgam and stainless steel wire, respectively.

After 24 -hour incubation, $100 \mu \mathrm{l}$ of $0.01 \%$ neutral red dye (Sigma, St. Louis, Missouri) were added to the culture medium in the 96-well microplates, which were incubated again for 3 hour at $370 \mathrm{C}$ so that the red dye could penetrate the live cells. Following this period of time, $100 \mu \mathrm{l}$ of $4 \%$ formaldehyde solution (Vetec, Rio de Janeiro, Brazil) in PBS (130 mM of NaCl; $2 \mathrm{mM}$ of KCl; $6 \mathrm{mM}$ of $\mathrm{Na} 2 \mathrm{HPO} 42 \mathrm{H} 2 \mathrm{O} ; 1 \mathrm{mM}$ of $\mathrm{K} 2 \mathrm{HPO} 41 \mathrm{mM} ; \mathrm{pH} 7.2$ ) were added in order to promote cell attachment to the plate. After 5 minutes, $100 \mu \mathrm{l}$ of $1 \%$ acetic acid (Vetec, Rio de Janeiro, Brazil) and $50 \%$ methanol (Vetec, Rio de Janeiro, Brazil) were added in order to remove the dye. After 20 minutes, a spectrophotometer (BioTek, Winooski, Vermont) at 492 $\mathrm{nm}$ wavelength $(\mathrm{I}=492 \mathrm{~nm})$ was used for data reading.

Data were compared by analysis of variance (ANOVA), and Tukey's multiple comparison test was used for identifying differences between the groups. Significance level was set at $p<0.05$. 


\section{RESULTS}

The results showed significant difference $(p<0.05)$ between the groups $N, R, Y, G$ and the stainless steel wire control (negative cytotoxicity control) at $1 \mathrm{~h}$ (Table II). Group Y produced the lowest value $(36.6 \% \pm 4.4 \%)$ and group $\mathrm{N}$ produced the more viability $(39.9 \% \pm 3.5 \%)$, both similar, whereas the viability of the amalgam was $30.8 \% \pm 5.9 \%$ (Table II).

After 24 hours, a decrease in cell viability was observed in all groups. Viability ranged from $20.1 \%$ to
$29.9 \%$, relative to the negative cytotoxicity control (Table II). The lowest viability $(20.1 \% \pm 6.0 \%)$ corresponded to group $R$, whereas the viability of the amalgam (positive cytotoxicity control) was more than observed in all groups, $29.9 \% \pm 4.0 \%$. The results showed statistically significant differences between all groups tested with stainless steel wire control (negative cytotoxicity control $)(p<0.05)$ at $24 \mathrm{~h}$. On the other hand, it did not have presented statistically significant difference between the groups tested ( $p>0.05)$ at 1 and $24 \mathrm{~h}$ (Table II).

Table I. Elastic and control groups used for the assays.

\begin{tabular}{ccccc}
\hline Groups & Trademark & Colour & Load & Reference number \\
\hline N & Morelli & Natural & Mean & $60-01-205$ \\
R & Morelli & Red & Heavy & $60-02-323$ \\
Y & Morelli & Yellow & Mean & $60-02-313$ \\
G & Morelli & Green & Light & $60-02-303$ \\
Positive Control & Dental copper amalgam. Pratic NG 2. Vigodent \\
Negative Control & Stainless steel wire. American Orthodontics. 0.019"x 0.025"
\end{tabular}

Table II. Dye-uptake technique. Descriptive statistics for optical density. Values followed by same letters are not significantly different $(p>0.05)$ for the same time. SD: standard deviation.

\begin{tabular}{|c|c|c|c|c|c|c|c|c|}
\hline \multirow[t]{3}{*}{ Groups } & \multicolumn{8}{|c|}{ Time } \\
\hline & \multicolumn{4}{|c|}{$1 \mathrm{~h}$} & \multicolumn{4}{|c|}{$24 \mathrm{~h}$} \\
\hline & Mean & Median & S. D. & Viable Cells (\%) & Mean & Median & S. D. & Viable Cells (\%) \\
\hline CC & $0.492^{a}$ & 0.528 & 0.052 & 100.0 & $0.582^{a}$ & 0.618 & 0.069 & 100.0 \\
\hline C- & 0.482 & 0.502 & 0.071 & 98.1 & 0.569 & 0.588 & 0.083 & 97.9 \\
\hline $\mathrm{C}+$ & 0.151 & 0.172 & 0.009 & 30.8 & 0.174 & 0.196 & 0.007 & 29.9 \\
\hline $\mathbf{N}$ & $0.196^{\mathrm{b}}$ & 0.228 & 0.007 & 39.9 & $0.131^{\mathrm{b}}$ & 0.148 & 0.008 & 22.6 \\
\hline $\mathbf{R}$ & $0.185^{\mathrm{D}}$ & 0.197 & 0.010 & 37.7 & $0.116^{\mathrm{D}}$ & 0.130 & 0.007 & 20.1 \\
\hline $\mathbf{Y}$ & $0.180^{\mathrm{D}}$ & 0.194 & 0.008 & 36.6 & $0.123^{\mathrm{D}}$ & 0.144 & 0.012 & 21.3 \\
\hline G & $0.190^{\mathrm{D}}$ & 0.202 & 0.008 & 38.8 & $0.117^{\mathrm{D}}$ & 0.128 & 0.010 & 20.2 \\
\hline
\end{tabular}

\section{DISCUSSION}

Allergy caused by latex proteins has been well documented (Palosuo et al., 2002), including immediate hypersensibility reactions (Wakelin \& White, 1999). Amongst the allergic reactions caused by orthodontic elastics, swelling and stomatitits, erythematous oral lesions, respiratory reactions, and even anaphylactic shock, the most severe form of allergy (Everett \& Hice, 1974; Tomazic et al., 1992), can be cited. Latex allergy occurs in $3-17 \%$ of the cases (Turjanmaa et al., 1996).
Allergy to natural latex occurs because of the presence of many types of proteins, and the powder covering the orthodontic elastics works as a transporter for these proteins. Therefore, the development of nonlatex elastics has become increasingly important for clinical usage (Hwang \& Cha).

Although the protocol of immersion tests for rubber materials has yet to be standardized, a static immersion test was performed during the cytotoxicity 
test. Moreover, because the elastics were not identical (despite the uniform $7.9 \mathrm{~mm}$ manufacturer's specification), it was impossible to create the same volume setting for the different groups. Therefore, instead of testing by volume through by embedding an elastic band into the macro-well plates for each group, the same weight of elastics was placed into separate flasks filled with Eagles' minimum essential medium to extract an elute.

We have decided to use dental copper amalgam and stainless steel wire as positive and negative controls (Table I), respectively, because they have proved to be adequate for this type of assay (Santos et al.). Dental amalgam is potentially cytotoxic due the presence of mercury, but there are also other neurotoxic substances depending on their composition and manufacturation (Lobner \& Asrar).

As sterilisation is a prerequisite for cytotoxicity assay, ultraviolet light was used in the present study for sterilising both sides of the elastics (Santos et al.) during 30 minutes. All the elastics were found to have the same colour and malleability following UV light sterilisation.

The percentage of viable cells was obtained by comparing the mean optical density (OD) of control cells (no contact with the materials) with that of cell cultures put in contact with different elastics, resulting in 50\% toxicity for the cell cultures (CC50) (Table II).

Evidence of this cytotoxic feature was shown following exposition of the elastics to cell culture medium. It was used in this experiment only two times of evaluation 1 and $24 \mathrm{~h}$, a time that, usually these elastics are changed to each $24 \mathrm{~h}$ for the patient.

Natural latex elastics from natural, red, yellow and green colours induced a greater amount of cell lysis at 24 hours compared to the time of $1 \mathrm{~h}$. A lowest viability was observed in all groups regardless of their colour, similar the viability of the amalgam (positive cytotoxicity control) at 1 and $24 \mathrm{~h}$, thus suggesting lowest biocompatible these latex elastics and supporting findings of Santos et al. as well. Holmes et al. (1993) have verified whether the colourants used in the fabrication of coloured latex could have some toxic effect. Their results showed that these colourants exhibited low toxicity. However, such an effect is clinically inoffensive. Variations occur in the composition of the latex elastics and this could explain the different results between the elastics.

As the powder covering the elastics of all manufacturers was removed before performing the in vitro studies, it was not possible to know whether this powder would have made any effect.

According to Schmalz, the great danger is that potentially cytotoxic intra-oral elastics could release substances that might be ingested by the patient over time, thus causing diseases resulting from a cumulative effect. It is known that latex is not entirely biocompatible as it may interact with foods (Turjanmaa et al.; Carey et al., 1997) and medications (Towse et al., 1995).

It is important for the practitioner to know how to manage patients presenting latex allergy and how to deal with this problem (Hain et al., 2007). The safety biocompatibility of silicone has been well proved through the use of mouth guards in dentistry (ChauvelLebret et al., 1999). An alternative for patients with allergy to latex is to use non-latex elastics, which can be used in orthodontics without jeopardizing the orthodontic treatment (Gandini et al., 2007).

One can conclude, that the Morelli intra-oral elastics were found to be highly cytotoxic, regardless of their colour and immersion time, suggesting a less biocompatibility of these elastics and greater possibility of stimulation to the allergic reactions.

DOS SANTOS, L. R.; MELO P. M.; OTAVIANO M. F. \& VILLELA, R. M. T. Citotoxicidad de los elásticos ortodònticos de látex. Int. J. Odontostomat., 4(1):81-85, 2010.

RESUMEN: El látex natural no entra en la categoría de materiales que se sabe del todo inofensivo. El objetivo del presente estudio in vitro es poner a prueba la hipótesis de que no hay diferencia en la citotoxicidad entre elásticos de látex natural de diferentes colores. El presente artículo compara diferentes elásticos intraorales de látex $(5 / 16=7,9 \mathrm{~mm})$. La muestra se dividió en cuatro grupos según su fabricante: Grupo N (elástico látex, Morelli), Grupo I (elástico de color rojo, Morelli) Grupo Y (elástico de color amarillo, Morelli) y el Grupo G (elástico color verde, Morelli). Pruebas de citotoxicidad se realizaron mediante el uso de medio de cultivo celular que contiene líneas celulares L-929 (fibroblastos de ratón). La citotoxicidad se evaluó mediante el test "dye-uptake", que se empleó en dos momentos diferentes (1 y 24 h). Los datos se compararon mediante análisis de varianza (ANOVA) y test de Tukey $(p<0,05)$. Los resultados mostraron una diferencia significativa $(p<0,05)$ entre los grupos $N, R, Y, G$ y la negativa citotoxicidad del control en 1 y $24 \mathrm{~h}(p<0,05)$, no han presentado diferencias significativas entre los grupos N, R, Y, G probado $(p>0,05)$ en 1 y $24 \mathrm{~h}$. Elásticos intraorales Morelli resultaron ser altamente citotóxicos, independientemente de su color y tiempo de inmersión. 


\section{REFERENCES}

Carey, A. B.; Cornish, K.; Schrank, P.; Ward, B. \& Simon, R. Cross-reactivity of alternate plant sources of latex in subjects with systemic IgE-mediated sensitivity to Hevea brasiliensis latex. Ann. Allergy Asthma. Immunol., 74:317-20, 1997.

Chauvel-Lebret, D. J.; Pellen-Mussi, P.; Auroyb, P. \& Bonnaure-Malleta, M. Evaluation of the in vitro biocompatibility of various elastomers. Biomaterials, 20:291-9, 1999.

Everett, F. G. \& Hice, T. L. Contact stomatitis resulting from the use of orthodontic rubber elastics: report of case. J. Am. Dent. Assoc., 88:1030-1, 1974.

Fiddler, W.; Pensabene, J.; Sphon, J. \& Andrzejewski, D. Nitrosamines in rubber bands used for orthodontic purposes. Food Chem. Toxicol., 30:325-6, 1992.

Gandini, P.; Gennai, R.; Bertoncini, C. \& Massironi, S. Experimental evaluation of latex-free orthodontic elastics' behaviour in dynamics. Prog. Orthod., 8:8899, 2007.

Hain, M. A.; Longman, L. P.; Field, E. A. \& Harrison, J. E. Natural rubber latex allergy: implications for the orthodontist. J. Orthod., 34:6-11, 2007.

Hanson, M. \& Lobner, D. In vitro neuronal cytotoxicity of latex and nonlatex orthodontic elastics. Am. J. Orthod. Dentofacial Orthop., 126:65-70, 2004.

Holmes, J.; Barker, M. K.; Walley, E. K. \& Tuncay, O. C. Cytotoxicity of orthodontic elastics. Am. J. Orthod. Dentofacial Orthop., 104:188-91, 1993.

Hwang, C. J. \& Cha, J. Y. Mechanical and biological comparison of latex and silicone rubber bands. Am. J. Orthod. Dentofacial Orthop., 124:379-86, 2003.

Kao, C. T,; Ding, S. J.; He, H.; Chou, M. Y. \& Huang, T. H. Cytotoxicity of orthodontic wire corroded in fluoride solution in vitro. Angle Orthod., 77:349-54, 2007.

Lobner, D. \& Asrari, M. Neurotoxicity of dental amalgam is mediated by zinc. J. Dent. Res., 82:243-6, 2003.

Neiburger, E. J. A case of possible latex allergy. J. Clin. Orthod., 25:559-60, 1991.

Neyndorff, H. C.; Bartel, D. L.; Tufaro, F. \& Levy, J. G. Development of a model to demonstrate photosensitizer-mediated viral inactivation in blood. Transfusion, 30:485-90, 1990.

Palosuo, T.; Alenius, H. \& Turjanmaa, K. Quantitation of latex allergens. Methods, 27:52-8, 2002.

Perrella, F. W. \& Gaspari, A. A. Natural rubber latex protein reduction with an emphasis on enzyme treatment. Methods, 27:77-86, 2001.

Santos, R. L.; Pithon, M. M.; Oliveira, M. V.; Mendes, G. S., Romanos, M. T. V. \& Ruellas, A. C. O. Cytotoxicity of intraoral orthodontic elastics. Braz. J. Oral Sci., 24:1520-5, 2008.

Schmalz, G. Use of cell cultures for toxicity testing of dental materials--advantages and limitations. J. Dent., 22(2):S6-11, 1994.

Snyder, H. A. \& Settle, S. The rise in latex allergy: implications for the dentist. J. Am. Dent. Assoc., 125:1089-97, 1994.

Tomazic, V. J.; Withrow, T. J.; Fisher, B. R. \& Dillard, S. F. Latex-associated allergies and anaphylactic reactions. Clin. Immunol. Immunopathol., 64:89-97, 1992.

Towse, A.; O'Brien, M.; Twarog, F. J.; Braimon, J. \& Moses, A. C. Local reaction secondary to insulin injection. A potential role for latex antigens in insulin vials and syringes. Diabetes Care, 18:1195-7, 1995.

Turjanmaa, K.; Alenius, H.; Mäkinen-Kiljunen, S.; Reunala, T. \& Palosuo, T. Natural rubber latex allergy. Allergy, 51:593-602, 1996.

Vande Vannet, B. M. \& Hanssens, J. L. Cytotoxicity of two bonding adhesives assessed by three-dimensional cell culture. Angle Orthod., 77:716-22, 2007.

Wakelin, S. H. \& White, I. R. Natural rubber latex allergy. Clin. Exp. Dermatol., 24:245-8, 1999.

Weiss, M. E. \& Hirshman, C. A. Latex allergy. Can. J. Anaesth., 39:528-32, 1992.

Correspondence to:

Rogério Lacerda dos Santos

Rua Ipatinga, 170, Planalto

Divinópolis- MG- CEP: 35501-191

BRAZIL

Email: lacerdaorto@hotmail.com lacerdaorto@bol.com.br

Received:19-01-2010

Accepted:22-02-2010 
